\title{
Organizational Path Dependence: A Process View
}

Organization Studies 32(3) $321-335$

(C) The Author(s) 201I

Reprints and permission: sagepub.co.uk/journalsPermissions.nav DOI: $10.1177 / 017084061039748$ I

www.egosnet.org/os

@SAGE

\section{Georg Schreyögg}

School of Business \& Economics, Freie Universität Berlin, Germany

\section{Jörg Sydow}

School of Business \& Economics, Freie Universität Berlin, Germany

\begin{abstract}
The structuring and behaviour of organizations is increasingly explained with the help of process theories, taking into account that history and sequencing matter. Among them, the notion of path dependence has gained prominence, in particular when an explanation for the rigidification of organizational routines and strategies is at stake. The distinguishing feature of this concept is its emphasis on self-reinforcing mechanisms when explaining the dynamics of narrowing down the scope of alternative actions in and among organizations. After having presented and discussed the theory of organizational path dependence, the paper highlights commonalities and contrasts between related concepts. Thereafter, the papers of this Special Themed Section will be introduced.
\end{abstract}

\section{Keywords}

path dependence, self-reinforcing processes, lock-in, imprinting, inertia, institutionalization, commitment, organizational change

\section{Introduction}

In recent years no notion has gained more attention when explaining the structuring and behaviour of organizations than the concept of process. The emphasis on processes has become an inevitable feature. Studying organizational processes, however, requires a template that specifies the idea of a process beyond the simple insight that a time span is implied, no matter whether one is taking a traditional approach towards organizational stability and change or buying into an ontology of organizational becoming (Tsoukas \& Chia, 2002). Three features seem to us particularly salient when aiming to substantiate an organizational process theory:

\section{Corresponding author:}

Georg Schreyögg, School of Business \& Economics, Freie Universität Berlin, Germany

Email: info@fu-schreyoegg.de 
- a process encompasses several (at least two) events, decisions and/or other types of actions;

- these events/actions do not happen separately, they are connected so that they amount to a sequence in its own order;

- the result (or, more often, the focused intermediate state) is basically imprinted by the foregoing course of actions and its characteristics: that is, 'history matters'.

Apart from these elementary features, another basic question is what gestalt the process is likely to take, for instance in terms of a teleological, life cycle, evolutionary or dialectical nature (e.g. Van de Ven \& Poole, 1995). A still popular theory of the teleological type is the behavioural theory of the firm that conceives organizational structures as the result of decision-making processes characterized by bounded rationality and political influences (Cyert \& March, 1963). Theories of organizational development and change often adopt a life-cycle perspective (Quinn \& Cameron, 1983), even if they include not only incremental but also radical, disruptive change (Romanelli \& Tushman, 1994). Population ecology (Hannan \& Freeman, 1977, 1984) is certainly among the most popular evolutionary approaches to change, and so is the more recent co-evolutionary theory (Koza \& Lewin, 1998). There are also other suggestions in terms of evolutionary thought. An increasing number of organization theories, for instance, explicitly conceptualize evolving organizational processes by taking a practice perspective (Jarzabkowski, 2008; Pentland \& Feldman, 2005; Schatzki, Knorr Cetina, \& Von Savigny, 2001). Discourse and structuration theories are examples of dialectical approaches emphasizing tensions and contradiction as drivers of organizational and interorganizational processes (De Rond \& Bouchikhi, 2004; Grant \& Hardy, 2004; Sydow \& Windeler, 1998).

Among the organizational process approaches there is a special group aiming to explain how organizational persistence comes about. This endeavour may seem paradoxical at first glance, but these concepts and theories highlight the other side of the coin of organizational processes. Studying organizational persistence and its underlying processes is now actually a flourishing domain among organizational theorists. Well known concepts are, for instance, structural inertia, imprinting, institutionalization, commitment or trajectories. In most cases, persistence is treated either as a starting point or process outcome, but the logic of the very process producing organizational persistence remains under-explored, by and large.

Among the candidates specifying the underlying logic of entrapping processes, self-reinforcing mechanisms stand out. Self-reinforcing mechanisms often unfold behind the backs of the actors and bring about an escalating situation with unexpected results. So far, very little attention has been given to those mechanisms in organizational process theories. This is surprising, given that in many cases self-reinforcing mechanisms play a role as drivers of organizational dynamics. Well known examples are, for instance, the increasing commitment of organizational decision-makers to a decision that is already recognized as suboptimal (Staw, 1984), or the routinization spiral underlying the development of bureaucratic organizations that, over time, become increasingly inert (Hannan \& Freeman, 1984). It is only the theory of organizational path dependence, however, that explicitly explores and exposes the dynamics of self-reinforcing mechanisms.

The emerging theory of organizational path dependence has received quite a lot of attention in organization and management research recently (Garud, Kumaraswany, \& Karnøe, 2010; Gruber, 2010; Kirchner, 2010; Sydow, Schreyögg, \& Koch, 2009; Thrane, Blaabjerg, \& Møller, 2010; Van Driel \& Dolfsma, 2010). It builds on the seminal work by Paul David (1985) and Brian W. Arthur (1994) but now goes well beyond that. The theory of organizational path dependence and its recent developments are the subject of this Special Themed Section, for which we received well over 20 submissions. ${ }^{1}$ 


\section{Organizational Path Dependence: Suggesting a Process Framework}

Becoming path-dependent represents a very special type of organizational process. At its heart is a tapering process, which dramatically narrows the scope of action over time. Valuable insights into the dynamic nature of entrapping or locking processes have already been provided by path studies from evolutionary economics and economic history, which, however, focus almost exclusively on technological innovation at the field or market level (Arthur, 1989, 1994; David, 1985, 1986; Dosi, 1982, 1997). In order to explain the dynamics of these processes, these studies have — as already mentioned - identified self-reinforcing processes as major drivers of becoming path-dependent. Translating the logic of technological path dependence into organizational path dependence could build on contributions from the institutional analysis of economic systems (North, 1990) as well as on more recent insights from historical institutionalism (e.g. Thelen, 1999) and political science (e.g. Pierson, 2000).

In order to better understand the process of becoming path-dependent, we suggest subdividing the whole process into three stages. As will be shown, these are governed by different causal regimes and constitute different settings for organizational action and decision-making (Sydow et al., 2009). Figure 1 illustrates the process across the three stages and aims to point out the different predominant regimes which, together, taper the organizational process.

Phase I - the Preformation Phase - can be characterized as a broad scope of action; choices cannot be predicted, but are influenced by prior events or initial conditions. Once a decision is made or an action taken, this choice may turn out to be a 'small event', which, often unintentionally, sets off a self-reinforcing process. This moment of entering into the dynamics of a selfreinforcing process can be conceived as a 'critical juncture' (Collier \& Collier, 1991) that ends the Preformation Phase. In the initial version of the theory of path dependence, Phase I was characterized as a completely open situation with no significantly restricted scope of action. The search for alternatives starts from scratch, decisions are unconstrained and the resulting choice is explained by rationality (Arthur 1989, 1994). However, such framing of the first stage in the tradition of the rational choice paradigm ignores the overarching relevance of history. In brief, history also matters in the Preformation Phase. Organizational choices are choices embedded in institutions, and that

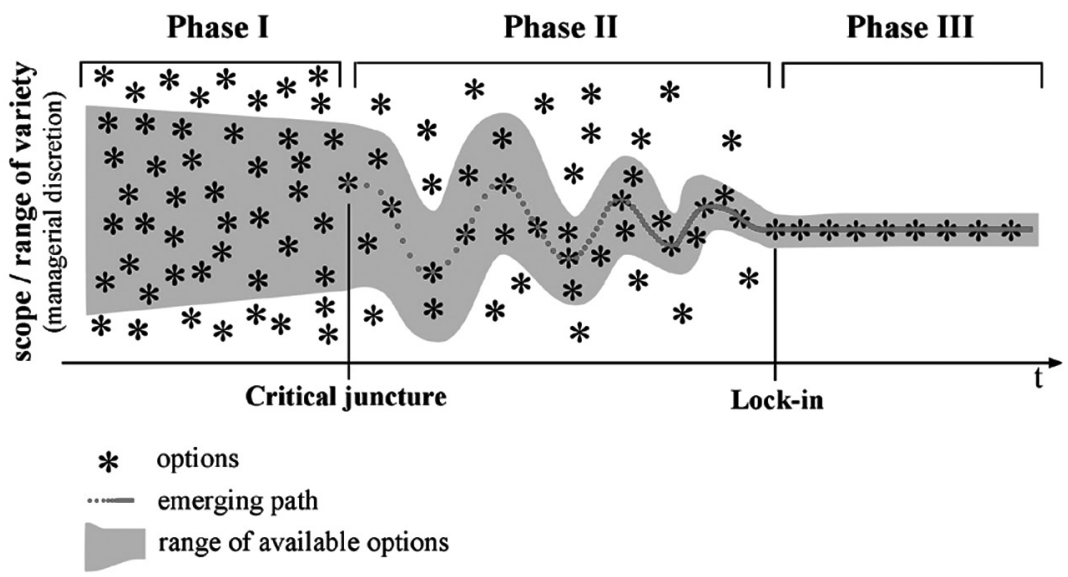

Figure I. The Constitution of an Organizational Path (Sydow et al., 2009, p. 692, modified) 
means they do not start from scratch but reflect, at least partially, the rules and the culture making up the institution (e.g. Child, 1997; Tolbert \& Zucker, 1996;). Conceiving the activities in the Preformation Phase thus has to account for foregoing imprints. The shadow in Phase I in Figure 1 is intended to indicate this inevitable institutional heritage.

Another related issue is the triggering of further reactions in Phase I. The initial choice in path dependence thought is conceived as a 'small event' (Arthur, 1994). While it is appealing to conceive of triggers of path dependence as small/random events, it is hard to find a logical or empirical necessity for this exclusive reliance on small/random events. As organizations are social systems and not natural entities, triggering events in organizations are likely to prove not so innocent, random and small (cf. also Bassanini \& Dosi, 2001). Irrespective of whether the initial actions are big or small, they can, however, never be considered causal determinants of path-dependent processes. The very point of path-dependent processes is that they are contingent in character and that the outcome cannot be known unless the process has been formed.

In Phase II - the Formation Phase - a new regime takes the lead: the dynamics of selfreinforcing processes. A dominant action pattern is likely to build up; alternative patterns face problems in getting attention and acceptance, which renders the whole process more and more irreversible. By implication, the range of options narrows and it becomes progressively difficult to reverse the central pattern of action, i.e. an organizational path is evolving. Decision processes in Phase II are, however, still contingent; they are 'non-ergodic', i.e. they are not accidental, and not fully predictable either. The course of action may still include unexpected developments. Phase II reflects the gradual emergence of an organizational path. An initially unknown logic happens to take the lead, favouring a particular decision or action pattern, and reproduces this over a certain period of time. This phase commences with a critical juncture at the passage from Phase I to II. A decision made or an action taken in Phase I amounts to a trigger for the further development of the organization or an organizational subsystem.

The unfolding of the process of path formation is driven by self-reinforcing mechanisms. Building on Arthur's $(1989,1994)$ conception of increasing returns and a broad range of positive feedbacks (Beyer, 2010) for a theory of organizational path dependence, four self-reinforcing mechanisms seem to be the most important:

- coordination effects;

- complementarity effects;

- learning effects;

- adaptive expectation effects.

Coordination Effects. Initially put forward in institutional economics (North, 1990), coordination effects build on the benefits of rule-guided behaviour: the more actors adopt and apply a specific organizational rule or routine, the more efficient the interaction is among these actors. When the behaviour of the actors is rule-guided, reactions can be anticipated and considered in advance, and consequently coordination costs can be significantly reduced. Hence, it becomes more attractive to adopt these rules the more other individuals follow these very same rules. An example that applies directly to organizations is working-time regimes, which guarantee efficient cooperation.

Complementarity Effects. Complementarities refer to synergy resulting from the interaction of two or more separate but interrelated resources, rules or practices (Pierson, 2000). In the case of complementarities, the advantages of repeatedly combining interrelated activities do not simply add up, they produce an additional surplus. This type of mechanism is at work when routines and/ 
or practices are interconnected in such a way that it becomes ever more attractive to exploit the synergies or - when referring to the reverse aspect - to save misfit costs caused by solutions deviating from the established organizational capability. As a result, distinct sets of activity patterns become progressively dominant (Leonard-Barton, 1995) and also deeply embedded in an organization ('deep structure').

Learning Effects. Learning effects hold that the more often an operation is performed, the more efficiency will be achieved when operating subsequent iterations. The operations are more skilfully performed (faster, more reliable and with fewer errors), which, in turn, means decreasing average costs per unit of output (Argote, 1999). And the more attractive the chosen solution becomes, due to accumulated skills and decreasing cost, the less attractive it is to switch to new learning sites (where the actors would have to start from scratch). Only sticking to the once chosen solution promises continued returns - although, as is well known, the resulting unit cost curve flattens after a while.

Adaptive Expectation Effects. These self-reinforcing effects relate to interactive building of preferences, which are not considered to be fixed dispositions but to develop in response to the expectations of others. Often quoted examples highlight the need for social belonging and the desire to end up on the winners' side. The more people are expected to prefer a particular product or service (and not another one), the more attractive it becomes (Leibenstein, 1950). In the context of organizations, the informal diffusion of practices often follows this logic (Szulanski, 1996). Organizational members are willing to adopt them because they expect others to do the same and wish to end up on the winners' side.

The transition from Phase II to Phase III — the Lock-in Phase — can be characterized by a further constriction, which eventually leads into an organizational lock-in, i.e. the dominant pattern gets fixed and develops a quasi-deterministic character; the process is fully bound to a path. Even new entrants into this field of action have to adopt it. When faced by more efficient alternatives or critical changes in the system's environment, decision processes and established practices tend to continue to reproduce this and only this particular outcome. The lock-in may be dominantly cognitive, normative or resource-based in nature; actual organizational lock-ins are most likely to be combinations of these three types of lock-in.

In its extreme form, the dominant pattern gains a deterministic character; all further decisions or actions are bound to replicate the path. This extreme form of lock-in has been found for technological solutions (e.g. the QWERTY keyboard). Considering organizational paths, however, the context seems to be significantly different, requiring a somewhat modified conception of lock-in. Due to their social character, organizational processes are more complex and ambiguous in nature. An organizational path theory should therefore conceptualize the final stage of a path-dependent process in a less restrictive way, leaving some scope for variation (similarly, Martin \& Sunley, 2006; Pierson, 2000; Thelen, 1999; Thrane et al., 2010). A corridor — as indicated by the shadow in Phase III in Figure 1 - may serve best to illustrate this reasoning.

Whatever the best conceptualization of an organizational lock-in, the most precarious feature of this stage is the risk of becoming dysfunctional because it is losing its capability to adapt to new circumstances or to better alternatives. Patterns - even lock-ins - which have proved successful for quite a while, may be called into question by new, more efficient alternatives, or changed internal or external circumstances may demand new solutions. The dark side of path dependence comes to the fore, as the system has lost its flexibility; it is confined to the existing path that replicates inefficient solutions (Leonhard-Barton, 1995; Schreyögg \& Kliesch-Eberl, 2007). 
To sum up, the proposed theory conceptualizes an organizational path as a social process that is initially, in Phase I, shaped by contingent choices leading to a critical juncture, which is triggered by a small or bigger event. Phase II, the actual Path Formation Phase, is governed by a regime of positive, self-reinforcing feedback loops, constituting and setting up a specific pattern of actions (social practices), which gains more and more predominance against alternative solutions to the extent that, at least potentially, leads into a potentially inefficient lock-in in Phase III.

\section{Competing Concepts in Organization Theory}

To clarify the specifics of a theory of organizational path dependence further, it seems advisable to compare it with related organization theories also aiming at explaining (often puzzling) organizational persistence. Since several organization theories elaborate on rigidifying practices or long-standing operational procedures in organizations, it seems worthwhile to discuss the overlaps and the distinctions using the concepts they provide. The most important of these are imprinting, commitment/sunk costs, structural inertia and institutional persistence.

\section{Organizational Imprinting}

More often than not, the notion of organizational path dependence is equated with imprinting effects of the past on present and future organizational behaviour (e.g. Collinson \& Wilson, 2006; Beckman \& Burton, 2008). The idea of imprinting starts with the insight that organizations founded at one time typically have a different social structure from those formed at another time. Stinchcombe (1965, p. 154) hypothesized that this phenomenon was due to the fact that 'organizations which are founded at a particular time must construct their social systems with the social resources available'. As they build new organizations, founders unconsciously use elements from their political, cultural and economic environment. Stinchcombe's major thesis holds that these initial elements may persist for years, or even decades, implying causal relationship between the specific historical context of founding and the organization's later structure. This is most convincingly demonstrated by Johnson (2007) in her study of the Paris Opera since its founding in 1669 by Pierre Perrin, who was supported in this activity by a powerful authority (Louis XIV).

The concept of 'imprinting' (Beckman \& Burton, 2008; Boeker, 1989; Marquis, 2003; Stinchcombe, 1965) now figures prominently in several theories of organization, not only the ones mentioned, but also in neo-institutionalism and population ecology (e.g. Baron, Hannan, \& Burton, 1999; Johnson, 2007). In essence, the founding entrepreneur - or the founding team - selects and incorporates historically specific elements at the time of founding. These elements may become routinized and may thereby come to influence/imprint an organization's structure and behaviour long after the founding phase. Hence, similar to organizational path dependence, the imprinting hypothesis assumes a reduction of managerial discretion. And this basic thesis is also represented in a way in the behavioural theory of the firm (Cyert \& March, 1963) and evolutionary theories (Nelson \& Winter, 1982; Weick, 1979). Both streams of theorizing organizational processes point to the important role of initial decisions and successive consolidation of routines and operational procedures as repositories of the organizational history. These routines and procedures are assumed to standardize organizational behaviour in terms of repetitive patterns, i.e. contributing alone or in combination to organizational persistence. Similarly, more recent cognitive organization theories put the emphasis on cognitive schemes and interpretative frames that are initially built and later become dominant in managerial actions (e.g. Gioia \& Sims, 1986; Schwenk, 2007). These initial frames and schemes imprint decision-making processes in organizations and, eventually, amount to replicated patterns (e.g. Tripsas \& Gavetti, 2000). 
While there are doubtless striking similarities between the organizational imprinting hypothesis and the theory of organizational path dependence, the process of becoming path-dependent starts at a different time and is governed by a different logic. Firstly, the set of imprinting features is set up at the beginning of the process; in a way, it is a ready-made scheme, which comes into existence and continues to influence structures and processes long after the founding phase (though it remains quite unclear why it continues to influence the processes). In contrast, the gestalt of a path is not clear at all in the initial stage; it is shaped by later processes that are initially unknown. Path dependence is an offspring of the dynamics of the process in question and not a repetition of initially selected features. Secondly, because of this developmental perspective, a theory of organizational path dependence - as opposed to the imprinting approach — aims at explaining the logic of the unfolding process of path formation. At the heart of this explanation - as has been argued above - are self-reinforcing mechanisms. It starts with contingency and triggering events bringing the process to a critical juncture, emphasizing the power of subsequent self-reinforcing processes, which may lead to a lock-in. The imprinting argument, by contrast, assumes that the initial conditions (at the time of founding an organization) matter most in explaining subsequent organizational structuring and behaviour. The imprinting argument is only sensitive to initial conditions as carriers of history, but ignores the later dynamics of the development. While initial conditions or choices are - as shown above - also important from a path dependence point of view, the intermediate actions and events between the initial imprints and the final outcome do, however, govern the core process.

This argument takes us to a third, more general difference. Both approaches advance different types of explanation. The imprinting hypothesis is based on a causal linear logic; the initial conditions and entrepreneurial choices, conditioned by contextual circumstances, amount to a dominating cause that brings about similar structures and choices in the future (effect). In the theory of organizational paths, by contrast, initial investments or random choices are not assumed to bring about path dependence inevitably. It is not a cause-effect, but rather a contingent relationship (or 'non-ergodic', as David [1985] put it). The process may take this road or another one, but the direction cannot be known until we know the process - therefore we cannot know the result of the process at the very beginning. Path dependence thought represents a type of non-linear reasoning.

\section{Commitment and Sunk Costs}

There is another stream of research that has clear connotations to the path dependence thesis, namely the notion of commitment. Various authors even equate both approaches, no matter whether the notion of commitment has its roots in social psychology (Staw, 1984) or strategic management (Ghemawat, 1991). The commitment thesis basically focuses on the binding forces of earlier spent energy or costs on later decisions at the individual or organizational level. By highlighting the influence of former decisions in terms of expenditures on current and future decision-making, the commitment argument was initially developed as a counterpoint to ahistorical rational choice thinking, including that promoted by neo-classical microeconomics.

The commitment argument includes two different views. The first view incorporates economics into strategic management and focuses on sunk costs and their relevance for future strategic decisions (Ghemawat, 1991). Sunk costs are expenses (money, time, passion, etc.) paid in the past, which can no longer be changed; they are irreversible ('sunk'). Even in the case of warning signals indicating that the current course of action may fail or when other more attractive (more efficient, more profitable, etc.) options are brought to the knowledge of the decision-makers, managers are often reluctant to pull out from the initial course of action. They persist with their strategy or 
business model because they are afraid to waste the initial investment. Besides fear of wasting money, further reasons have been developed to explain this tendency. Among them, there is emotional boundedness to a strategy or an investment; also, decision-makers may be unwilling to admit that their prior choice is likely to fail (Brockner, 1992). In many studies (cf. Staw, 1997), the persistence became even stronger during the course of events; the commitment escalates.

From a rational choice point of view these forms of persistence do not need deeper exploration; they simply represent forms of flawed, irrational decision-making, which can be overcome by training people to behave more rationally, in particular after faulty decisions have been made. Microeconomists consequently warn against taking sunk costs into consideration because they are likely to distort any rational investment decision calculus (see, however, McAfee, Mialon, \& Mialon, 2010). However, these arguments only hold true in a highly idealized world of neo-classical premises.

The reality of organizations is quite different. This is acknowledged by the second, more individual approach to commitment in organizational behaviour. Staw (1984) in particular has made it clear that individuals tend to hold on to a decision they have made. This makes it easier for them to avoid cognitive dissonances, admitting failure and demonstrating personal inadequacies. Under particular circumstances, not least reputational concerns, illusions of control, time constraints, external pressure or particular group dynamics, their commitment to a former decision may even escalate. In consequence, because of escalating commitment, it becomes even more difficult to change a course of action once chosen (cf. Staw, 1997). It is important to see that in this theory, failure is there right from the beginning.

In sharp contrast to imprinting, commitment — in particular, escalating commitment in decisionmaking - refers to a dynamic process that can easily amount to a lock-in (Edwards, 2001; Keil et al., 2000; Staw, 1984, 1997). In this case, it is not the initial conditions, but rather the (increasing!) individual or organizational commitment to this initial investment, which is at the heart of the process and is therefore likely to bring about rigidity and lock-in. At first sight, these are striking similarities to the process of becoming path-dependent, since the process is also driven as a reinforcing mechanism. On the other hand, escalating commitment theory starts with a faulty decision from the very beginning and explains why people nevertheless stick to this failing course of action. Path dependence analyses focus on different phenomena. Organizational paths start with efficient, or at least satisfying, decisions that may get frozen during the course of action and end up in a lock-in. Studies of organizational path dependence are therefore interested in the dynamics that stimulate and nurture these unintended shifts in the logic of functioning. Accordingly, the theory of organizational path dependence relies on specific social mechanisms that are likely to bring about such shift dynamics. Such path-building dynamics are - as argued above - assumed to be activated by self-reinforcing mechanisms. In contrast, the thesis of escalating commitment is based on the dynamics of psychological or strategic misconduct; the underlying dynamics are nurtured by individual motives, such as feelings of guilt and fears of loss, or by organizational strategies trying to preserve the value of investments once they have been made.

Apart from escalating commitment, which highlights commitment as problematic, Ghemawat (1991) brought another important dimension in the commitment debate to the fore by suggesting that commitment should be analysed in terms of a trade-off. All economic activities require resource allocation and investment, which are the basis of any economic success. Due to the law of limited resources, realizing one project means selection, i.e. committing resources to this project and not to others. Investing resources hence means losing flexibility at the same time. Other, possibly more attractive options in the future can no longer be realized because the resources are more or less irreversibly committed. This constitutes a dilemma: commitment is the basic (and 
unavoidable) precondition for generating income. At the same time, commitment implies a loss of flexibility in terms of opportunity costs. As dilemmas cannot be solved, Ghemawat suggests looking for balancing models designed to keep a system flexible and committed (see also Schreyögg \& Sydow, 2010).

Another related research stream on commitment is neo-institutionalist economics - transaction cost theory (Williamson, 1985, 1993) and incomplete contract theory (Hart, 1995), in particular. They share with the path dependence approach the emphasis on decision-making and the acknowledgment that former decisions have an impact upon current settings. Transaction cost theory, for example, argues that high asset specificity as a result of initial and subsequent investment commitment leads to high transaction cost, which in turn favours a hierarchical pattern of exchange relationships. Williamson (1993) is right when he states that in this respect history (commitment) matters in transaction cost reasoning. Governance structures are explained by foregoing decisions on commitment and control mechanisms. While acknowledging this historical feature, however, this (comparatively) static approach cannot capture the dynamics of these processes, which are not path-dependent in a strict sense, in particular with regard to self-reinforcing dynamics and inefficiencies. This approach holds that the present institutional solution has proved efficient. As critics as well as advocates of more dynamic versions of this theory would argue (e.g. Langlois \& Robertson, 1995; Lazonick, 1991; Nooteboom, 2004), asset specificity may even trigger a process of escalating commitment of resource endowments to a particular relationship. Under these circumstances, a path is likely to develop and a lock-in may result from the commitment dynamics. Following this argument, Leiblein and Miller (2003, p. 842), investigating transaction- and capability-based influences on firm boundaries, concluded that:

'a firm that chose to internalize an activity in the past, perhaps due to the need for high levels of transactionspecific investment, may be more likely to remain integrated in the present, even if the current levels of asset specificity and uncertainty suggests that market transactions are attractive'.

However, to our knowledge, the theoretical core components of the process - the unfolding of self-reinforcing mechanisms and the emergence of lock-in - have unfortunately not yet been conceptualized, even in these dynamic versions of the theory. Furthermore, the question arises why such inefficient forms of organizations can survive within the logic of neo-institutional economics. Are other governance forms with less rigidity not likely to outperform them?

\section{Structural Inertia}

Structural inertia is a core concept of population ecology, stating the positive as well as the negative consequences of organizational stability relative to its more or less dynamic environment (Carroll \& Harrison, 1994; Hannan \& Freeman, 1977, 1984; Levinthal, 1997). A major source of structural inertia is the (assumed) necessity of routinizing and institutionalizing organizational activities in order to secure reliability and accountability in performance and, finally, survival in basically competitive environments. The resulting structural inertia, in other approaches often seen as resulting from organizational age and (over)size (e.g. Kelly \& Amburgey, 1991; Sastry, 1997), is conceived in early stages as a necessary precondition to effective organizational acting. Subsequently, however, this inertia threatens the organization's survival because of a lack of strategic adaptability and a possible mismatch with changed environmental conditions.

Again, the phenomenon in focus is somewhat similar to that of organizational path dependence, but the explanations differ considerably. Organizational inertia comes about via blind structural 
reproduction, but - again - we are not provided with a clear process theory that explains how the dynamics evolve beyond stabilization through routines, via a mixture of minor variation and major retention processes. Carroll and Harrison (1994) at least mention the possible importance of positive feedback and self-reinforcement mechanisms in the ecological model of density dependence. In contrast to the theory of path dependence, population ecologists consider structural inertia as a property of 'ripe' organizations, while path dependence is a special phenomenon that is likely to emerge in organizations only under the conditions specified in detail above - irrespective of age. In consequence, inert organizations are certainly a likely candidate for further inquiry into organizational path dependence. The outcome of the inquiry may nevertheless demonstrate that the development of a particular organization, though featuring rigidity, does not exhibit properties of organizational path dependence. Hence, while structural inertia may well be an outcome of a path-dependent process, not every kind of inertia is caused by one or more mechanisms that are characteristic of such path-building processes.

\section{Institutional Persistence}

Like structural inertia, organizational persistence is a possible, perhaps even likely outcome of institutionalization processes. The process of institutionalization is at the core of neo-institutionalism in organization theory (Lawrence, Winn, \& Jennings, 2001; Powell \& DiMaggio, 1991; Scott, 2008; Tolbert \& Zucker, 1996). By focusing on the process of institutionalization as a response to normative, mimetic and/or coercive forces in general, and on the sedimentation of structure over a longer period of time in particular (e.g. Hargadon \& Douglas, 2001; Lawrence et al., 2001), this approach addresses phenomena similar to path dependence. This is particularly the case when the institutionalization process leads not only to the diffusion of a certain practice within an organization or an organizational field, but to the sedimentation and legitimation, even taken-for-grantedness and 'objectification' of this practice (Berger \& Luckmann, 1966). The result is likely to be rather stable or even persistent. More often than not, this process is considered by institutionalists to be path-dependent, though in most cases without any serious reference to the theory of path dependence. The confusion of institutionalization and organizational persistence (as a likely outcome of this process) with organizational path dependence comes somewhat as a surprise, as does the underutilization of the latter concept by institutionalists, for, as one of the main protagonists of neo-institutionalism argued two decades ago, 'path-dependent arguments hold considerable promise for the explanation of institutional persistence' (Powell, 1991, p. 194).

Organizational persistence is considered first and foremost as resulting from adaption processes of organizations to the legitimacy needs of the symbolic environment (Meyer \& Rowan, 1977). Despite its focus on institutionalization, this theory does not, however, provide a theoretical understanding of the logic of persistence-building processes and dependence dynamics. The major reason for this is that its explanation refers basically to external imperatives (seeking external legitimization as the major driver) and not to the internal process of self-referential reproduction of evolving patterns (see, however, Eden, 2004; Holm, 1995). In contrast to path dependence, the end of the process is open; it is unclear whether the registered stability or even persistence may pave the way for, or even end up in, a lock-in, and if so, why and when. Institutional stability is typically achieved with the help of structures and practices that are considered intelligible and legitimate and, not least for this reason, more often than not, taken for granted. Thus, while the result of this process, i.e. organizational persistence, comes close to the idea of structural inertia, the explanation puts significantly less emphasis on routinization as the driver of this outcome. Because of its focus on the external environment, however, the explanation is even more at odds with organizational 
Table I. Organizational Path Dependence and Related Concepts

\begin{tabular}{|c|c|c|c|c|c|}
\hline & $\begin{array}{l}\text { Organizational } \\
\text { path } \\
\text { dependence }\end{array}$ & $\begin{array}{l}\text { Organizational } \\
\text { imprinting }\end{array}$ & $\begin{array}{l}\text { Commitment } \\
\text { and sunk cost }\end{array}$ & $\begin{array}{l}\text { Structural } \\
\text { inertia }\end{array}$ & $\begin{array}{l}\text { Institutional } \\
\text { persistence }\end{array}$ \\
\hline $\begin{array}{l}\text { Initial } \\
\text { conditions }\end{array}$ & $\begin{array}{l}\text { Important } \\
\text { trigger, but } \\
\text { inconclusive } \\
\text { impact }\end{array}$ & $\begin{array}{l}\text { Decisive } \\
\text { trigger }\end{array}$ & Decision & $\begin{array}{l}\text { Not so } \\
\text { important, form } \\
\text { basically shaped } \\
\text { through the } \\
\text { process }\end{array}$ & $\begin{array}{l}\text { Not so } \\
\text { important, form } \\
\text { basically shaped } \\
\text { through external } \\
\text { forces }\end{array}$ \\
\hline $\begin{array}{l}\text { Governance } \\
\text { of process }\end{array}$ & $\begin{array}{l}\text { Self-reinforcing } \\
\text { mechanisms in } \\
\text { path formation } \\
\text { phase; } \\
\text { endogenous }\end{array}$ & $\begin{array}{l}\text { Reproduction; } \\
\text { endogenous }\end{array}$ & $\begin{array}{l}\text { Holding on to } \\
\text { former decision; } \\
\text { endogenous; } \\
\text { self-reinforcement } \\
\text { in the case } \\
\text { of escalating } \\
\text { commitment }\end{array}$ & $\begin{array}{l}\text { Reproduction; } \\
\text { endogenous, } \\
\text { but primarily } \\
\text { driven by } \\
\text { exogenous } \\
\text { forces }\end{array}$ & $\begin{array}{l}\text { Reproduction } \\
\text { and diffusion via } \\
\text { institutionalization; } \\
\text { primarily } \\
\text { exogenous }\end{array}$ \\
\hline $\begin{array}{l}\text { Outcome of } \\
\text { process }\end{array}$ & $\begin{array}{l}\text { Path } \\
\text { dependence, at } \\
\text { least potential } \\
\text { inefficiency }\end{array}$ & Persistence & $\begin{array}{l}\text { Persistence and } \\
\text { inefficiency }\end{array}$ & $\begin{array}{l}\text { Persistence; } \\
\text { efficient and } \\
\text { later inefficient }\end{array}$ & Persistence \\
\hline Predictability & $\begin{array}{l}\text { Initially not } \\
\text { given, but } \\
\text { becomes } \\
\text { clearer in path } \\
\text { formation } \\
\text { phase }\end{array}$ & $\begin{array}{l}\text { Given right } \\
\text { from the start }\end{array}$ & $\begin{array}{l}\text { Given right from } \\
\text { the start }\end{array}$ & $\begin{array}{l}\text { Given after } \\
\text { establishing } \\
\text { a successful } \\
\text { pattern }\end{array}$ & $\begin{array}{l}\text { Given when } \\
\text { knowing the } \\
\text { environmental } \\
\text { forces }\end{array}$ \\
\hline $\begin{array}{l}\text { Level of } \\
\text { analysis }\end{array}$ & $\begin{array}{l}\text { Organization, } \\
\text { applicable to } \\
\text { other levels as } \\
\text { well }\end{array}$ & Organization & $\begin{array}{l}\text { Organization, } \\
\text { sometimes } \\
\text { population }\end{array}$ & $\begin{array}{l}\text { Organization, } \\
\text { sometimes } \\
\text { population }\end{array}$ & $\begin{array}{l}\text { Organization, } \\
\text { sometimes field }\end{array}$ \\
\hline
\end{tabular}

path dependence, which highlights endogenous processes of self-reinforcement. In consequence, only institutionalization processes that are triggered by a smaller or bigger event and driven by self-reinforcing mechanisms should be classified as path-dependent. The notion of institutional paths, therefore, should be reserved for this phenomenon, whose empirical relevance still has to be established.

Table 1 summarizes the commonalities and differences between organizational path dependence and these seemingly similar and yet quite distinct concepts.

\section{Overview of the Papers that Follow}

As argued above, the theory of organizational paths provides a better understanding of some quite specific forms of organizational stability and institutional persistence. Because of this specialized focus, it provides important insights into how and under what circumstances organizations are likely to tap into a process narrowing down the scope of actions. This is demonstrated well by the two papers included in the Special Themed Section.

The paper by Jochen Koch explores the phenomenon of organizational path dependence in a thorough empirical study of quality newspapers in Germany. He is particularly interested in 
strategic persistence and how strategic paths are 'inscribed' into organizations. Towards this end, the author distinguishes mechanism inscription and pattern inscription and considers in detail the role of organizational context in the process of path development.

The second paper, by Jean-Philippe Vergne and Rudolphe Durand, addresses the increasingly popular conception of the dynamic capabilities approach and its various links to the phenomenon of path dependence. Following Teece, Pisano and Shuen (1997), the authors argue that path dependence is a constitutive property of any dynamic capability. At the same time, the dynamic capabilities approach tries to overcome this very dependence. The authors elaborate on the resulting paradoxes and their inherent complexity. Finally, they provide suggestions for how to overcome or handle these dilemmas.

Taken together, the contributions to this Special Themed Section show that a process view on organizational path dependence is on its way; a view that fits well with current interests in organizational practices and routines, rules and resources, contracts and cognitions, dynamics and change - and, on a more overarching theoretical level, with the logic of systemic processes, which are more often than not of hidden, and self-reinforcing character.

\section{Note}

1 On this occasion, we would like to thank Hari Tsoukas, former editor-in-chief of OS, for his enthusiasm and advice, and David Courpasson, the present editor-in-chief, for helping us to finalize this Special Themed Section. In addition, we are grateful to more than two dozen reviewers that commented on the manuscripts submitted, namely Klaus Beck, Richard Boland, Simon Collinson, Stanislav Dobrev, Deborah Dougherty, Stephan Duschek, Lars Engwall, Simone Ferriani, Daniel Geiger, Bob Gephart, John Hagedoorn, Klaus Heine, Markus Helfen, Gregory Jackson, Paula Jarzabkowski, Louise Knight, Ken Koput, Kalle Lyytinen, Stephan Manning, Andrew Nelson, Sue Newell, Günther Ortmann, Margaret A. Peteraf, Arie Rip, Douglas Robinson, Dieter Sadowski, Harry Scarbrough, Cornelius Schubert, Nicolaj Siggelkow, Udo Staber, Martin Stack, Ray Stokes, Ludwig Theuvsen, Henk Volberda and Arnold Windeler. Finally, we thank the German Research Foundation (DFG) for supporting the Pfadkolleg Research Centre at Freie Universität Berlin (www.pfadkolleg.de).

\section{References}

Argote, Linda (1999). Organizational learning: Creating, retaining and transferring knowledge. Boston: Kluwer Academic.

Arthur, W. Brian (1989). Competing technologies, increasing returns, and lock-in by historical events. Economic Journal 99, 116-131.

Arthur, W. Brian (Ed.). (1994). Increasing returns and path dependency in the economy. Ann Arbor: University of Michigan Press.

Baron, James N., Hannan, Michael T., \& Burton, M. Diane (1999). Building the iron cage: Determinants of managerial intensity in the early years of organizations. American Sociological Review, 64, 527-547.

Bassanini, Andrea P., \& Dosi, Giovanni (2001). When and how chance and human will can twist the arms of Clio: An essay on path dependence in a world of irreversibilities. In Raghu Garud \& Peter Karnøe (Eds.), Path dependence and creation (pp. 41-68). Mahwah, NJ: Erlbaum.

Beckman, Christine M., \& Burton, M. Diane (2008). Founding the future: Path dependence in the evolution of top management teams from founding to IPO. Organization Science, 19(1), 3-24.

Berger, Peter, \& Luckmannn, Thomas (1966). The social construction of reality - A treatise in the sociology of knowledge. New York: Penguin.

Beyer, Jürgen (2010). The same or not the same - On the variety of mechanisms of path dependence. International Journal of Social Sciences, 5(1), 1-11.

Boeker, Warren (1989). Strategic change: The effects of founding and history. Academy of Management Journal, 32, 489-515. 
Brockner, Joel (1992). The escalation of commitment to a failing course of action: Toward theoretical progress. Academy of Management Review 17, 39-51.

Carroll, Glenn R., \& Harrison, J. Richard (1994). On the historical efficiency of competition between organizational populations. American Journal of Sociology 100, 720-749.

Child, John (1997). Strategic choice in organization studies: Retrospect and prospect. Organization Studies, $18,43-76$.

Collier, Ruth B., \& Collier, David (1991). Shaping the political arena: Critical junctures, the labor movement, and regime dynamics in Latin America. Princeton, PA: Princeton University Press.

Collinson, Simon, \& Wilson, David C. (2006). Inertia in Japanese organizations: Knowledge management routines and failure to innovate. Organization Studies, 27, 1359-1387.

Cyert, Richard M., \& March, James G. (1963). A behavioral theory of the firm. Englewood Cliffs, NJ: Prentice-Hall,

David, Paul A. (1985). Clio and the economics of QWERTY. American Economic Review, 75(2), 332-337.

David, Paul A. (1986). Understanding the economics of QWERTY: The necessity of history. In W. N. Parker (Ed.), Economic history and the modern economist (pp. 30-49). Oxford: Blackwell.

De Rond, Mark H., \& Bouchikhi, Hamid (2004). On the dialectics of strategic alliances. Organization Science, $15,56-69$.

Dosi, Giovanni (1982). Technological paradigms and technological trajectories: A suggested interpretation of the determinants and directions of technical change. Research Policy, 11(3), 147-162.

Dosi, Giovanni (1997). Opportunities, incentives and the collective patterns of technological change. Economic Journal, 107, 1530-1547.

Eden, Lynn (2004). Whole world on fire: Organizations, knowledge, and nuclear weapons devastation. Ithaca, NY: Cornell University Press.

Edwards, John C. (2001). Self-fulfilling prophecy and escalating commitment: Fuel for the Waco fire. Journal of Applied Behavioral Science 37, 343-360.

Garud, Raghu, Kumaraswany, Arun, \& Karnøe, Peter (2010). Path dependence or path creation? Journal of Management Studies, 47, 760-774.

Ghemawat, Pankaj (1991). Commitment. New York: Free Press.

Gioia, Dennis A., \& Sims, Henry P. (1986). Social cognition in organizations. In Henry P. Sims \& Dennis A. Gioia (Eds.), The thinking organization (pp. 1-19). San Francisco: Jossey Bass.

Grant, David, \& Hardy, Cynthia (2004). Introduction: Struggle with organizational discourse. Organization Studies, 25, 5-13.

Gruber, Marc (2010). Exploring the origins of organizational paths: Empirical evidence from newly founded firms. Journal of Management, 36, 1143-1167.

Hannan, Michael T., \& Freeman, John (1977). The population ecology of organizations. American Journal of Sociology, 82, 929-964.

Hannan, Michael T., \& Freeman, John (1984). Structural inertia and organizational change. American Sociological Review, 49(2), 149-164.

Hargadon, Andrew B., \& Douglas, Yellowlees (2001). When innovations meet institutions: Edison and the design of the electric light. Administrative Science Quarterly, 46, 476-501.

Hart, Oliver (1995). Firms, contracts, and financial structure. New York: Oxford University Press.

Holm, Petter (1995). The dynamics of institutionalization: Transformation processes in Norwegian fisheries. Administrative Science Quarterly, 40, 398-422.

Jarzabkowski, Paula (2008). Shaping strategy as a structuration process. Academy of Management Journal, $51,621-650$.

Johnson, Victoria (2007). What is organizational imprinting? Cultural entrepreneurship in the founding of the Paris Opera. American Journal of Sociology, 113(1), 97-127.

Keil, Mark, Tan, Bernard C. Y., Wei, Kwok-Kee, Saarinen, Timo, Tuunainen, Virpi, \& Wassenaar, Arjen (2000). A cross-cultural study on escalation of commitment behavior in software projects. MIS Quarterly, 24, 299-325.

Kelly, Dawn, \& Amburgey, Terry L. (1991). Organizational inertia and momentum: A dynamic model of strategic change. Academy of Management Journal, 34, 591-612. 
Kirchner, Stefan (2010). Organizational identities and institutions. Dynamics of the organizational core as a question of path dependence. MPIfG Working Paper 10/4. Cologne: Max Planck Institute for the Study of Societies.

Koza, Mitch, \& Lewin, Arie Y. (1998). The co-evolution of strategic alliances. Organization Science, 9, $255-264$.

Langlois, Robert N., \& Robertson, Paul L. (1995). Firms, markets, and economic change: A dynamic theory of business institutions. London: Routledge.

Lawrence, Tom B., Winn, Monika I., \& Jennings, P. Deveraux (2001). The temporal dynamics of institutionalization. Academy of Management Review, 26, 624-644.

Lazonick, William (1991). Business organization and the myth of the market economy. Cambridge: Cambridge University Press.

Leibenstein, Harvey (1950). Bandwagon, snob, and Veblen effects in the theory of consumer's demand. Quarterly Journal of Economics, 64(2), 183-207.

Leiblein, Michael J., \& Miller, Douglas J. (2003). An empirical examination of transaction- and firm-level influences on the vertical boundaries of the firm. Strategic Management Journal, 24, 839-859.

Leonard-Barton, Dorothy (1995). Wellsprings of knowledge. Boston: Harvard Business School Press.

Levinthal, Dan A. (1997). Adaptation of rugged landscapes. Management Science, 43, 934-950.

Marquis, Christopher (2003). The pressure of the past: Network imprinting in intercorporate communities. Administrative Science Quarterly, 48, 655-689.

Martin, Ron, \& Sunley, Peter (2006). Path dependence and regional economic evolution. Journal of Economic Geography, 6, 395-437.

McAfee, R. Preston, Mialon, Hugo M., \& Mialon, Sue H. (2010). Do sunk costs matter? Economic Inquiry, 48, 323-336.

Meyer, John W., \& Rowan, Brian (1977). Institutionalized organizations: Formal structure as myth and ceremony. American Journal of Sociology, 83, 340-363.

Nelson, Richard R., \& Winter, Sidney G. (1982). An evolutionary theory of economic change. Cambridge, MA: Harvard University Press.

Nooteboom, Bart (2004). Inter-firm collaboration, learning and networks. London: Routledge.

North, Douglas C. (1990). Institutions, institutional change and economic performance. Cambridge: Cambridge University Press.

Pentland, Brian T., \& Feldman, Martha (2005). Organizational routines as a unit of analysis. Industrial and Corporate Change, 14, 793-815.

Pierson, Paul (2000). Increasing returns, path dependence, and the study of politics. American Political Science Review, 94, 251-267.

Powell, Walter W. (1991). Expanding the scope of institutional analysis. In Walter W. Powell \& Paul DiMaggio (Eds.), The new institutionalism in organizational analysis (pp. 183-203). Chicago: University of Chicago Press.

Powell, Walter W., \& DiMaggio, Paul (Eds.). (1991). The new institutionalism in organizational analysis. Chicago: University of Chicago Press.

Quinn, Robert E., \& Cameron, Kim (1983). Organizational life cycles and shifting criteria of effectiveness: Some preliminary evidence. Management Science, 29, 33-51.

Romanelli, Elaine, \& Tushman, Michael L. (1994). Organizational transformation as punctuated equilibrium: An empirical test. Academy of Management Journal, 37, 1141-1166.

Sastry, M. Anjali (1997). Problems and paradoxes in a model of punctuated organizational change. Administrative Science Quarterly, 42, 237-275.

Schatzki, Theodore R., Knorr Cetina, Karin, \& Von Savigny, Eike (Eds.). (2001). The practice turn in contemporary theory. London: Routledge.

Schreyögg, Georg, \& Kliesch-Eberl, Martina (2007). How dynamic can organizational capabilities be? Towards a dual-process model of capability dynamization. Strategic Management Journal, 28, 913-933.

Schreyögg, Georg, \& Sydow, Jörg (2010). Organizing for fluidity? On the dilemmas of new organizational forms. Organization Science, 21, 1251-1262. 
Schwenk, Charles R. (2007). The cognitive perspective on strategic decision making. Journal of Management Studies, 25, 41-55.

Scott, Richard (2008). Institutions and organizations (3rd ed.). Thousand Oaks, CA: Sage.

Staw, Barry M. (1984). The escalation of commitment to a course of action. Academy of Management Review, 6, 577-587.

Staw, Barry M. (1997). The escalation of commitment: An update and appraisal. In Zur Shapira (Ed.), Organizational decision making (pp. 191-215). Cambridge: Cambridge University Press.

Stinchombe, Arthur (1965). Social structures and organizations. In James G. March (Ed.), Handbook of organizations (pp. 142-193). Chicago: Rand McNally.

Sydow, Jörg, Schreyögg, Georg, \& Koch, Jochen (2009). Organizational path dependence: Opening the black box. Academy of Management Review, 34, 689-709.

Sydow, Jörg \& Windeler, Arnold (1998). Organizing and evaluating interfirm networks - A structurationist perspective on network management and effectiveness. Organization Science, 9, 265-284.

Szulanski, Gabriel (1996). Exploring internal stickiness: Impediments to the transfer of best practice within the firm. Strategic Management Journal, 17(S2), 27-43.

Teece, David J., Pisano, Gary, \& Shuen, Amy (1997). Dynamic capabilities and strategic management. Strategic Management Journal, 18, 509-533.

Thelen, Kathleen (1999). Historical institutionalism and comparative politics. Annual Review of Political Science, 2, 369-404.

Thrane, Sof, Blaabjerg, Steen, \& Møller, Rasmus Hanneman (2010). Innovative path dependence: Making sense of product and service innovation in path dependent innovation processes. Research Policy, 39 , 932-944.

Tolbert, Pamela S., \& Zucker, Lynn (1996). The institutionalization of institutional theory. In. Stewart R. Clegg, Cynthia Hardy, \& Walter R. North (Eds.), Handbook of organization studies (pp. 175-190). London: Sage.

Tripsas, Mary, \& Gavetti, Giovanni (2000). Capabilities, cognition, and inertia: Evidence from digital imaging. Strategic Management Journal, 21, 1147-1161.

Tsoukas, Hari, \& Chia, Robert (2002). On organizational becoming: Rethinking organizational change. Organization Science, 13, 567-582.

Van de Ven, Andrew H., \& Poole, Marshall Scott (1995). Explaining development and change in organizations. Academy of Management Review, 20, 510-540.

Van Driel, Hugo, \& Dolfsma, Wilfred (2010). Imprinting, path dependence and metaroutines: The genesis and development of the Toyota production system. In Georg Schreyögg \& Jörg Sydow (Eds.), The hidden dynamics of path dependence (pp. 35-48). London: Palgrave Macmillan.

Weick, Karl (1979). The social psychology of organizing (2nd ed.). Redding, MA: Addison-Westley.

Williamson, Oliver E. (1985). The economic institutions of capitalism. New York: Free Press.

Williamson, Oliver E. (1993). Transaction cost economics and organization theory. Industrial and Corporate Change, 2(2), 107-156. 